This study has attested to the truth of Pindar's famous claim that

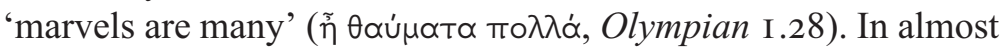
every genre and mode of ancient Greek literary writing, the significance of wonder as a category of experience can be probed in ways which provide radically new and defamiliarising perspectives on familiar material. But amidst this general polyphony, there remain continuities in how thauma and thaumata are defined, configured and conceived. In this concluding epilogue three case studies are presented with a twofold purpose in mind: to trace out and reiterate some of the main trends, tendencies, changes and continuities in the treatment of thauma in Greek literature from Homer to the early Hellenistic period, while simultaneously suggesting some further directions for the study of wonder and the marvellous in antiquity and beyond.

The first section builds on this study's discovery of the growing significance of thauma as a philosophical concept. Following on from the last chapter's examination of the place of wonder in the Republic's Cave Allegory, the significance of thauma in Plato's last work, the Laws, is examined. The discussion then moves to Rome in the first century BCE to consider the rise of another philosophical principle relating to thauma: the idea of not marvelling at anything at all (nil admirari). In the second section, the growing impact of thauma on ancient discussions of the relationship between nature and artifice is again reassessed through an examination of the place of wonder in the mechanical treatises of the first-century CE engineer Hero of Alexandria. Finally, in the third section, the idea of the marvel as a textual phenomenon is revisited through an examination of the first extant description of the reading and use of Greek paradoxographical texts, an account 


\section{Epilogue: Thaumata Polla}

which appears in the Noctes Atticae of the second-century CE Roman miscellanist Aulus Gellius, whose work also provides an opportunity to begin to think about the reception of Greek wonder and wonders in Roman culture.

In each of these sections I am not aiming to be exhaustive or absolute, either in my summing up or in my suggestions for further questions of interest. Rather, in the same spirit of Plato and Aristotle with which I opened this study, I want once again to suggest that thauma is only a starting point for new and renewed inquiry.

\section{I Thauma as the Beginning of Philosophy - or Nil Admirari?}

Over the course of this book, it has become apparent just how much the importance of thauma as a concept in Greek philosophical thinking has been underrated in previous scholarship. By the time one reaches the work of Aristotle and his Peripatetic followers, the significance of thauma as a concept is already well-established in the realm of aesthetic and rhetorical theory (see Aristotle's Poetics and Rhetoric), in biology, zoology and science more generally (see Aristotle's biological writings and the works of the paradoxographers), and also in relation to the notion of what philosophy itself is and does (see Aristotle's Metaphysics). The significance of thauma for the Peripatetics is not surprising, since it is in Plato's work that thauma really emerges for the first time as a fully conceptualised and complex term of philosophical hermeneutics. By the end of the fifth century BCE, the cultural discourse of thauma and thaumata, and particularly of their effects on audiences and viewers, is fully ready for the various philosophical uses to which Plato puts it. The fact that sight and vision, from the beginning of the Greek literary tradition, remain the sensory realm in which thauma exercises its greatest impact accounts to some extent for Plato's pronounced interest in the concept as a vehicle for expressing more general and complex concerns about human sensory experience of the phenomenal world, mimesis, thinking, and the origins of philosophy itself. At the same time, the fact that thauma exercises a simultaneous emotional and cognitive 
8. I Thauma as Beginning of Philosophy - or Nil Admirari?

effect on its subjects means that it becomes a vital concept in the philosopher's broader exploration of human psychology. For Plato, thauma is not only a response to the most unfamiliar and distant objects and experiences, or to experiences provoked by and related to the divine rather than the human realm, as it primarily was in the past - though these associations do remain. It is also the radically ambivalent effect of contemporary man-made spectacles which aim, above all else, to delight and distract. The inherent doubleness and variability which thauma possesses as a response to experiences which are able to provoke cognitive advancement, while at the same time risking a sort of dazzling cognitive stasis, is part of what makes wonder such a potent concept in Plato's philosophical arsenal.

This is nowhere clearer than in the Laws, Plato's final work. In this dialogue thauma plays a part in the explanation of the workings of human psychology itself. Plato presents us with three old men - an unnamed Athenian, a Cretan called Clinias and a Spartan named Megillus - who embark upon a discussion of the relative advantages and disadvantages of the legislative practices and constitutions of different cities and cultures in an attempt to define the best laws for the foundation of a new,

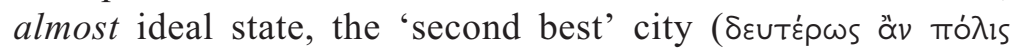

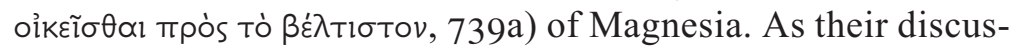
sion progresses, the question of what the best type of education might be for this new city's inhabitants soon arises. It is in the context of this question that, relatively early on in the discussion, the Athenian Stranger - the Laws' dominant, often Socrates-like guiding philosophical voice - returns to the image of thaumata, those puppet-like objects which we have seen being deployed by the strange thaumatopoioi who populate Plato's image of the Cave, to describe the workings of human psychology $(644 d-e)$ :

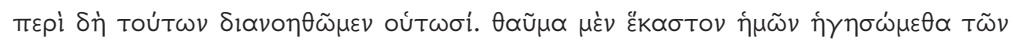

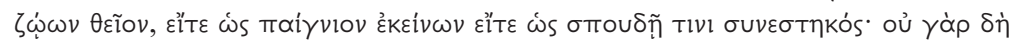

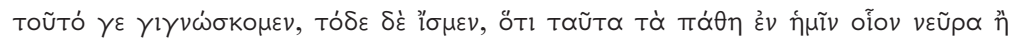

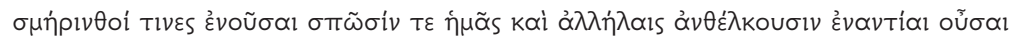

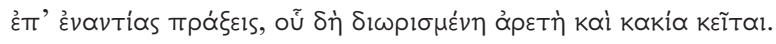




\section{Epilogue: Thaumata Polla}

Let us think this matter over in the following way. Let's suppose that each of us living creatures is a thauma belonging to the gods, put together to be either a toy of theirs or for some serious reason. We do not know why we were made, but we do know this much: that the feelings, like cords or strings inside us, both pull us along and, being opposed to one another, in mutual opposition they pull us towards opposite actions, where the dividing line between goodness and badness lies.

The Athenian Stranger goes on to explain that there is one particularly forceful cord pulling inside us which we should always try and follow over all others: 'the golden and holy cord of reason,

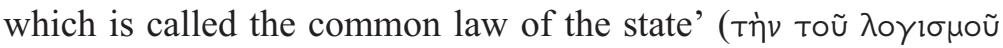

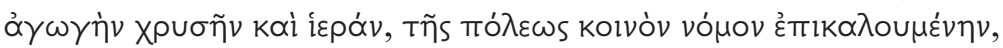
645a). The pull of this cord is, however, 'gentle rather than

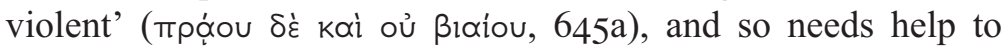
ensure that we follow it rather than the other impulses.

To begin to unpack this enigmatic image it is necessary to establish what kind of object the Athenian Stranger is comparing every human being to when he suggests that each and every one of us is similar to a 'thauma belonging to the gods' ( $\theta \alpha \tilde{\mu} \mu \alpha . . . \theta \varepsilon i ̃ o v)$. The most common interpretation of this phrase is something like 'puppet of the gods' or 'divine puppet', with the 'cords or strings' ( $v \varepsilon \tilde{\rho} \rho \alpha$ iे $\sigma \mu \eta \dot{p} \rho \imath \theta \circ i$ ) inside us corresponding to the cords which control a marionette-type object. It is important to understand the way in which the thauma is thought to function in relation to its cords and strings in this passage, as it affects our interpretation of the way in which human psychology, and the gods' influence on our psychology, is supposed to function. Although many previous commentators have built substantial readings of this passage by conceiving of the 'thauma belonging to the gods' as a marionette controlled by external strings, the whole point of this image is that the cords and strings described are internal rather than external: as a result, the thauma described here functions like an automaton rather than an externally controlled marionette. ${ }^{\mathrm{I}}$ The fact that

\footnotetext{
I The issue is complicated by the fact that there is a degree of overlap between the categories of puppet and automaton in antiquity: see Cappelletto (20I I) 325, Shershow (I995) 3-4 and Cambiano (I994) 622. For recent interpretations of the 'thauma belonging to the gods' as a type of externally operated marionette see e.g. Kurke (20I3) I 23 n. I, who suggests that the image describes puppets 'worked by strings or wires from above'; see also Moore (20I4) 40: 'a marionette would seem to be the more appropriate image
} 
cords and strings are involved is perfectly congruous with this interpretation of the Athenian Stranger's biological thaumata as automata, since we know that ancient automata and self-moving mechanisms were made to move through the use of a system of internal cords which were wound up and operated with the actions of weights, counterweights and pulleys. ${ }^{2}$ In fact, it was the automaton's apparent ability to move itself and become animate without continued input from elsewhere that led to the use of thauma as a synonym for such objects, since, as discussed in Chapter 2, the transgression of the boundaries between animate and inanimate and nature and artifice in objects of art or craft which appear to be so lifelike that they almost move is often said to be a prime cause of wonder, and indeed becomes a topos of ancient art criticism and ekphrasis.

Moreover, it is important to note that the common identification of the thaumata in this passage with puppets or marionettes is to a great extent a result of the influence of the description of the thaumata in the Republic's Cave Allegory. As discussed in the last chapter, in that passage it is clear that the men compared to 'marvel-makers' (thaumatopoioi) are certainly in charge of the objects described as thaumata that are causing the shadows being cast upon the wall of the Cave. These thaumatopoioi-like men therefore seem to be undertaking some sort of form of shadow puppetry. But it is essential to note that although the shadows in

rather than a wind-up toy'; cf. also Meyer (20I5) I78 and Schofield (20I6) I35-40. But the mention of cords and strings does not necessarily imply that the thauma is externally operated. In fact, the whole point of the image is that these cords and strings are internal impulses which act inside us. For this reason, the image necessarily refers to an object operated through the pull of internal cords. We are in fact dealing with the image of an automaton here: it is clear that the mechanisms of ancient automata would have depended on an internal system of cords which used weights and counterweights to cause various motions. Frede (20I0) I I6 discerns this point and its significance correctly: 'Although thauma is commonly translated as "puppet", this translation is misleading if it suggests that humans are mere marionettes whose strings are pulled by the gods. For, as the further descriptions show, the "puppet's" behaviour is not determined by the higher powers; it depends, rather, on the workings of its own strings. Hence, Plato seems to have in mind wind-up toys that move by themselves, rather than marionettes.' Annas (20 I I) 8 also gets it right: 'Plato is thinking, not of puppets on strings, but of toys which move around by themselves (a kind of clockwork wind-up toy).'

2 See Section 2 below on the treatises of the engineer Hero of Alexandria for more detailed descriptions of how wondrous (and possibly real-life) automata actually worked in antiquity. 


\section{Epilogue: Thaumata Polla}

this passage are made to appear through the external agency of the thaumatopoioi-like men, they are not seen as such by the people who are watching the performance in the Cave, since the shadows they see displayed before them seem to move of their own accord. This is what makes them thaumata: the effect is actually one of autonomous motion.

The Athenian Stranger's comparison of each living being to a 'thauma belonging to the gods' thus returns us to questions concerning thauma which have their roots as far back as the Homeric poems: the divide between human and divine, animate and inanimate, natural and man-made. From Homer onwards, we find spontaneously moving, automatous objects of divine craft labelled as thaumata. For example, divine craft is inextricably linked to the creation of automata when Thetis visits Hephaestus in Iliad I 8 and catches a glimpse of him in the act of making selfmoving tripods ( $18.372-7)$ :

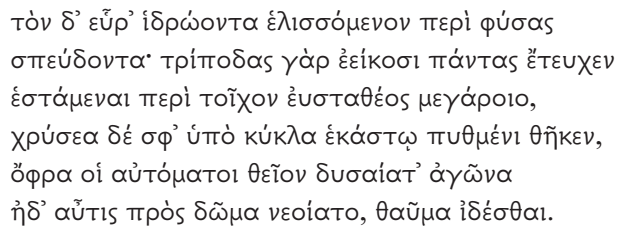

She found him sweating as he rushed around his bellows; for he was making tripods, twenty in total, to stand around the wall of his well-built hall, and he put golden wheels under the base of each, so that they would be able to make their way into the assembly of the gods of their own accord and go back again to his house, a wonder to see.

The self-movement of these tripods lies at the heart of their marvellous effect and is what renders them a particular 'wonder to see' ( $\theta \alpha \tilde{u} \mu \alpha$ i $\delta \varepsilon \dot{\varepsilon} \sigma \alpha$ l). These self-moving tripods become the archetypal examples of automata in the Greek literary tradition, along with similarly lifelike moving golden handmaidens, also made by Hephaestus, which aid the god in his work. ${ }^{3}$ The particular connection of these objects to the god's craft is important: once again we see that early conceptions of the marvellous are linked

3 Il. I8.4I7-I8: 'And the golden handmaidens, like living girls, moved swiftly to support

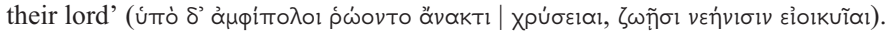


explicitly to the power of the divine. In Plato's Laws, the Athenian Stranger hits upon this image of automata-like thaumata as a means of suggesting that humans, like automata, are similarly created by the gods, and that each person also has the capability, if set moving in the right direction, to become an object of wonder. Plato is thus playing once again on the double-edged nature of thauma and thaumatic objects in this dialogue in a way which differs from his approach in the Republic. In the Cave Allegory there, thaumata represent a dangerous distraction from cognitive advancement when their powers of astonishment are wielded by the wrong hands; the Laws, in contrast, establishes that we ourselves might become objects of thauma, belonging to the gods themselves, if only we follow the pull of the 'golden cord' of reason which guides us correctly, like the motions of an automaton that are wisely and decorously programmed in advance in accordance with Reason.

The inherent potential doubleness of thauma and its effects thus accounts for Plato's use of the image of thaumata in the Laws and elsewhere. However, it was not always the case in antiquity that the positive potential of thauma as a philosophical concept was recognised. In fact, many Hellenistic philosophical schools went on not only explicitly to disavow the significance of thauma's place within philosophy but even went so far as to advise against succumbing to wonder and its effects entirely. In these philosophical traditions, the potentially disturbing emotional effects of thauma on the mind and soul are clearly thought to outweigh any positive effects that wonder may produce as a catalyst for (re)cognition and inquiry. The most famous surviving summation of this response to the effects of wonder is surely Horace's Epistle I.6, which begins with a warning about wonder which the rest of the poem goes on to elaborate in more detail $(\mathrm{I}-8)$ :

nil admirari prope res est una, Numici, solaque quae possit facere et servare beatum. hunc solem et stellas et decedentia certis tempora momentis sunt qui formidine nulla imbuti spectent: quid censes munera terrae, quid maris extremos Arabas ditantis et Indos, ludicra quid, plausus et amici dona Quiritis, quo spectanda modo, quo sensu credis et ore? 


\section{Epilogue: Thaumata Polla}

To marvel at nothing, Numicius, is almost the one and only thing which is able to make and keep you happy. Some men can view the sun up there, and the stars, and the seasons passing with the stars' predictable movements, untouched by any emotional disturbance: what do you think of the gifts of the earth, what of those of the sea, which enriches far-distant Arabians and Indians, what of the theatrical shows, the applause, or the favour of the friendly Roman citizen - in what manner, with what feeling and expression do you think they should be viewed?

Horace here warns his addressee Numicius against precisely the sorts of marvellous phenomena we have seen associated with wonder throughout this study. The warning against marvelling at the sight of phenomena such as the potentially distracting and specious spectacles of the theatre is conventional enough, but Horace goes further here. Even those experiences which philosophers such as Aristotle would encourage us to wonder at above all else - the marvellous phenomena of the natural world and the celestial realm - are classed as problematic causes of wonder precisely because they risk opening the viewer up to some degree of emotional disturbance.

This view, which denies wonder a place in both philosophy and everyday life, is very different from Platonic and Aristotelian attitudes towards thauma which have been outlined in the previous chapters. In choosing to examine the potential benefits and difficulties of the art of not marvelling in this Epistle, Horace is drawing on attitudes towards philosophical wonder which developed after Plato, Aristotle, and their respective schools. ${ }^{4}$ The principle of not wondering in order to avoid emotional disturbance seems to share certain similarities with Epicurean ideas about ataraxia (imperturbability) and Stoic concepts of apatheia (equanimity), as other texts from the first century BCE onwards which mention the ideal of wondering at nothing make clear. For example, Cicero mentions this principle in his discussion of how best to alleviate grief in book 3 of the Tusculan Disputations. He argues that because evil is harder to bear when it comes unexpectedly, it is best to exercise foresight and be prepared for all

${ }^{4}$ On Horace's eclectic drawing together of the teachings of various contemporary philosophical schools with this injunction against marvelling, and on this Epistle more generally, see e.g. Rudd (I993) 70, Mayer (1994) I57, McCarter (2015) I07-I5; see also Armstrong (2004) $284-5$ on the relation of the maxim nil admirari to Epicureanism. 
emotional disturbances. A key means of achieving this is wondering at nothing when it occurs, and being prepared for anything that might come to pass (nihil admirari cum acciderit, nihil, ante quam evenerit, non evenire posse arbitrari, 3.30). Strabo, who was roughly contemporaneous with Horace, offers a similarly Stoically-inflected take on this principle in relation to the natural world in his Geography. In the first book, he tells us (I.3.I6) that he will discuss multiple examples of wonderprovoking natural phenomena, such as the creation of a new island after the eruption of a volcano under the sea, to encour-

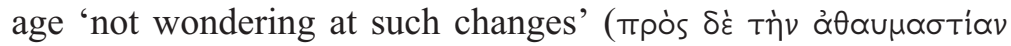

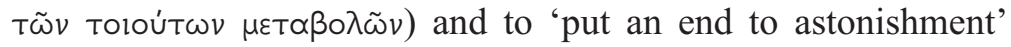

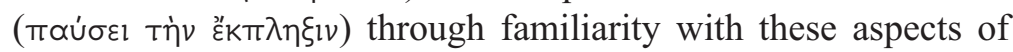
nature and geography. Later in the first century CE, Seneca the Younger offers yet another such Stoic view of the virtues of not marvelling, when he argues (Epistulae 8.5) that nothing except the soul is worthy of wonder, since 'nothing seems great to a soul which is itself great' (nihil praeter animum esse mirabile, cui magno nihil magnum est).

As these texts suggest, the place of wonder remained a matter of considerable debate in Roman philosophy. In fact, it is possible that Plato himself may have been reacting to certain aspects of this tradition of not wondering which were discussed by previous thinkers. In later discussions of the thought of Pythagoras and Democritus there is evidence that wonder's place in philosophical thinking was already an issue of concern. For example, Plutarch reports (Moralia 44b) that many people in his day misinterpret the Pythagorean saying that philosophy had given him the advantage of "wondering at

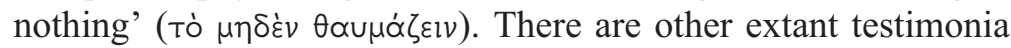
of the atomist Democritus' supposed advice to wonder at nothing which again point to the possible emotional disturbance which thauma causes as potentially problematic. In the De finibus, Cicero notes that Democritus said that the study of natural philosophy should result in a tranquillity of mind or a freedom from fear, a form of happiness which he termed euthumia (contentment) or athambia (freedom from 
wonder/imperturbability). ${ }^{5}$ Strabo associates similar terminology with Democritus, noting that not marvelling at things was approved of by the atomist (and other philosophers) since it is associated with a concomitant lack of emotional disturbance and therefore with imperturbability. ${ }^{6}$ Although it is difficult to assess precisely how widespread such views were before Plato's time due to the paucity and lateness of the testimonia, it is nevertheless clear that the potentially disturbing emotional effects of thauma were a matter of some concern even before Plato was writing, and were certainly of even greater concern in the thinking of many later Hellenistic philosophical schools. In this study, I have inevitably been so concerned with marvelling at things that the notion of not marvelling - which seems to become more fully developed in the later Hellenistic philosophical schools - is not one that I, constrained both by necessities of space and chronological focus, have been able to investigate in any great detail. But the place of thauma as a key term of the philosophical tradition after Plato and Aristotle is certainly an area that would reward further study.

\subsection{Mediating between Gods and Men, Nature and Artifice: Automata and Thauma in Hero of Alexandria's Mechanical Treatises}

One aspect of change in the conception of what thauma is and does between the Archaic and the Hellenistic periods which this

5 Cic. Fin. 5.29.87: tamen ex illa investigatione naturae consequi volebat bono ut esset

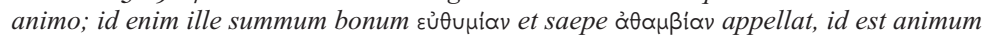
terrore liberum (Nevertheless he [i.e. Democritus] desired that a cheerful disposition would ensue from his inquiries into nature, since that man says that contentment, and often imperturbability (that is, a mind free from terror), is the greatest good).

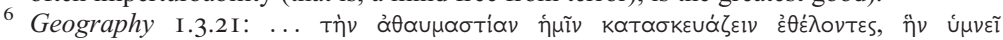

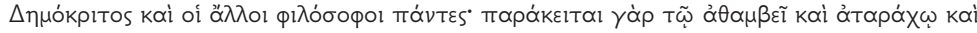

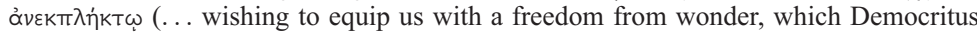
goes on about, as do all the other philosophers, for freedom from wonder is mentioned along with freedom from emotional disturbance and freedom from fear). Two fragments preserved in Stobaeus also mention athambia as a concept associated with Democritus.

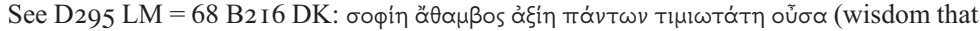
is free from wonder is worthy, since it is the most honourable thing of all) and D $322 \mathrm{LM}=$

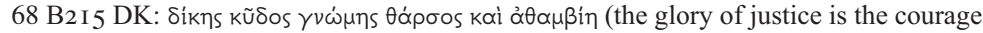
and freedom from wonder of thought). 
study has drawn out is the degree of its relation to the divine and to the natural world. Thauma is often strongly associated with the gods in Archaic poetry, as an effect of divine epiphany or of divinely-crafted artworks, and of music, song and poetry which somehow involves divine presence. Over the course of the Classical period, the association of thauma with human action becomes gradually stronger, with a concomitant rise in the perception that man-made objects or actions which aim at provoking thauma somehow inherently produce potentially deceptive effects. This is not to say, however, that the association between thauma and the divine sphere ever disappeared entirely. Instead, the relation of wonder to the gods, and its position as a mediating factor in mortal interactions with them, only became more complicated as time passed, rather than ebbing away completely.

As we saw above in the discussion of the divine thauma in the Laws, by Plato's time the long cultural association of thauma with objects created by and relating to the divine goes hand in hand with the simultaneous association of wonder with man-made marvelmaking (thaumatopoiia or thaumatourgia), an art which produces pure spectacles that aim primarily to delight and distract. The fact that the 'thauma belonging to the gods' ( $\theta \alpha \tilde{\mu} \mu \alpha \ldots \theta \varepsilon \tilde{0} \mathrm{v})$ which is used to reflect upon the workings of human psychology in the Laws is an automaton-like object is also significant because it hints at another transgression of conceptual boundaries to which wonder has always been linked: the line between nature and artifice. Since thauma is often conceived of as an effect caused by the extreme mimetic verisimilitude of inanimate artworks which somehow seem to turn into animate, living creatures, it is no surprise that the figure of the marvellous automatous object of craft should become a potent means of exploring the dividing line between nature and artifice more generally. Perhaps the predominant reason for the sense of wonder provoked by automata seems to be connected to the fact that the cause of such a mechanism's initial movement is unknown, often leading to speculation about divine or supernatural influence, or a sense of uncertainty about whether a given object - usually a simulacrum of a living being really is a natural or artificial one. Certainly, the widespread 


\section{Epilogue: Thaumata Polla}

suspicion of divine agency on seeing actions which appear to occur of their own accord makes sense, since in the absence of a known physical cause for a given event, its attribution to the gods provides a customary and reliable explanatory framework for what would otherwise be inexplicable.

This tendency to posit divine agency remains a potent aspect of the automaton's thaumatic appeal throughout antiquity. By the late Hellenistic period, there is evidence that thauma played a central role in theoretical discussions concerning the purpose, construction and effects of self-moving devices. In this period, automaton-building becomes a branch of the newly emerging discipline of mechanics. The significance of thauma in the development of this scientific discipline's own self-fashioning becomes clear when we examine the mechanical treatises of the engineer Hero of Alexandria. ${ }^{7}$ Hero's dates have long been disputed, but he is now generally placed in the latter half of the first century CE, although his writings on automata-making draw heavily on the work of an earlier Hellenistic predecessor, Philo of Byzantium (late third/early second century BCE). ${ }^{8}$ Two of Hero's treatises, Peri Automatopoietikes and Pneumatica, focus in particular on the construction of automatous devices. Peri Automatopoietikes is concerned entirely with the construction of two complex and very different automata: a moving altar of Dionysus, and a mechanical theatre in which the actions of a Sophoclean tragedy play out in miniature form. In contrast, Hero's Pneumatica contains descriptions of various smaller automatous mechanisms. Thauma occupies an important position in the proems of both treatises. At the beginning of Peri Automatopoietikes, Hero explains why the

7 On the importance of thauma and its connection to philosophy in Hero's work, see Tybjerg (2003) 443-66. Berryman (2009) 52-3 disagrees with Tybjerg regarding the importance that actual theorists such as Hero placed on thauma in the practice of mechanics, arguing that wonder was valued purely as an effect on the audience rather than something to strive towards for its own sake. On the importance of thauma within the discipline of mechanics in antiquity see also Cambiano (I994) 6I 7-2I.

${ }^{8}$ On the question of Hero's dates, which are based on the possible mention of an eclipse dated to 62 CE in his treatise Dioptra, see Murphy (I995) 2 and Berryman (2009) I34. See Berryman (2009) I23-30 on Philo of Byzantium's work; cf. Roby (20I6) 266-7 on the relationship between the work of Philo and Hero on automata. 
making of automata appealed to the engineers of the past (I.I):

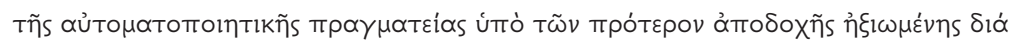

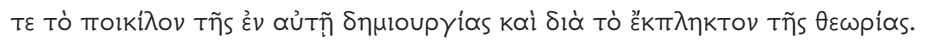

The field of automata-making was thought worthy of approval by previous authorities on account of the variety of the craftsmanship which it entails and because of the astonishing nature of the sight it provides.

In fact, Hero goes on to inform us that those engineers of the past who crafted automata were actually known as 'wonder-workers on account of the astonishing nature of the sight created'

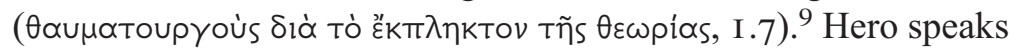
in similar terms in the proem of the first book of his Pneumatica, when he notes the potentially astonishing effects which can be created when the powers of air, earth, fire and water are properly harnessed (I.proem. I 2-I7):

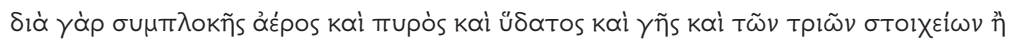

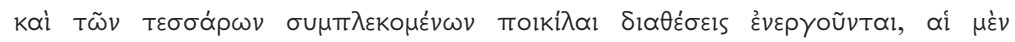

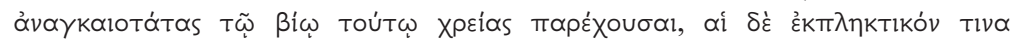

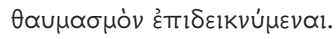

For various compositions are put in action through the combination of air and fire and water and earth and the joining of three or four elements, some of which supply the most necessary needs of life, while others put an astonishing wonder on display.

It is precisely through the combination of the powers produced by these four elements that the automatic devices which Hero goes on to describe in the Pneumatica will produce their wondrous effects. Indeed, when we look more closely at the function and effects of the automatous mechanical devices described, it becomes clear that the claims in each proem for the significance of thauma in the

9 It is possible that such wondrous automata-making engineers of the past actually existed, since in addition to the mention of automatous thaumata in Plato's Laws, discussed above, there are several other mentions of the past production of possibly real fourthcentury BCE automata: for example, automata are mentioned by Aristotle at Metaph. 983aI2-I4, Gen. an. 734b9-I4, De motu an. 70IbI-I7; Archytas of Tarentum was said to have produced a flying dove (see Gell. NA IO.I2.8-IO); a slime-exuding snail which moved of its own accord was said to have been included in a procession of Demetrius of Phaleron (see Polyb. I2. I3.9). On the difficulties of assessing these accounts as evidence for the production of actual automata see Berryman (2003) 344-69. 
mechanical sphere are indeed borne out. One thing that immediately strikes us is the fact that a significant number of the automata in both treatises are explicitly connected to temples or to religious ritual more broadly. ${ }^{\text {IO }}$ The most spectacular example is the first automaton described in Peri Automatopoietikes (3.I-I9.5): a moving altar of Dionysus which contains a figure of the god standing before an altar within a miniature shrine, surrounded by maenads and with a panther at his feet. Once the engineer has performed the necessary preparations and placed the automaton down its amazing actions begin: 'after a short time, although everyone is stood far off, it will wheel itself out to a predetermined position, and when it is still the altar in front of Dionysus will blaze up. And either milk or water will be squirted out of Dionysus' thyrsus, and wine will flow out of his wine cup onto the panther lying at his feet.' ${ }^{\text {I I }}$ Nor are wondrous aural effects neglected as the automatic display continues, as Hero's description of what happens next makes clear: 'and the Bacchants will go around the shrine in circles dancing and the din of drums and cymbals will arise'. ${ }^{\text {I2 }}$ Once these actions are completed the automaton will then come to a natural stop. Despite the extreme complexity of these mechanical actions, no further human intervention is needed once the automaton has been set in place, since every movement takes place as a result of a complex system of unseen weights, counterweights, pulleys and cords within the device itself. This inability to see the inner workings of the automaton is a crucial element of the thauma created, since from the observer's point of view the automaton appears to be operating through its own - or perhaps Dionysus' - agency.

There are numerous other examples of automatous mechanisms which aim to evoke an epiphanic and wondrous sense of divine presence in Hero's Pneumatica. Again, many of these devices are

Io $\mathrm{Cf}$. Lebrère (20I5) $3 \mathrm{I}-53$ on our evidence for the use of automata in the earlier Hellenistic world as an aspect of the religious practice of Ptolemaic monarchs.

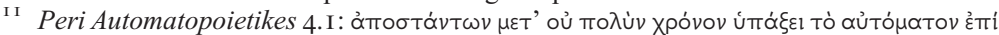

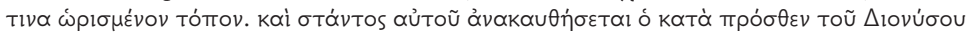

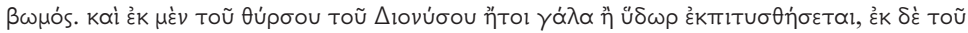

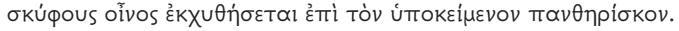

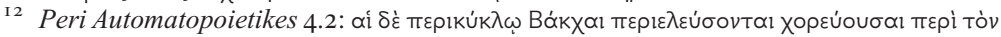

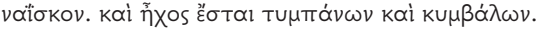


connected to temples. For example, Hero describes how to construct altars with various automatic effects, including some with 'surrounding figures which pour libations when the fire is lit'

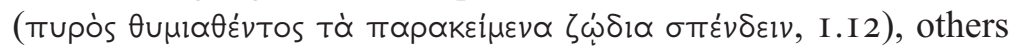
where 'a snake hisses when the figures set up beside the altar pour

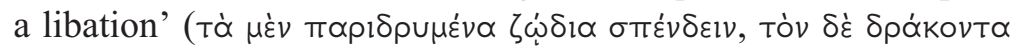

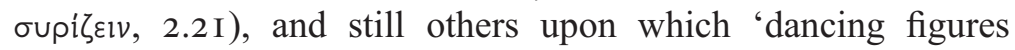

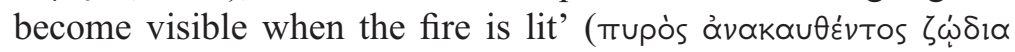

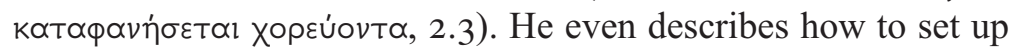
complex mechanisms for a small shrine which cause 'the doors to open up automatically when sacrifices are burnt, and close up

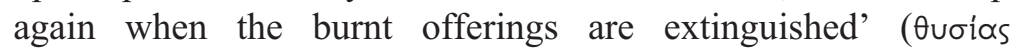

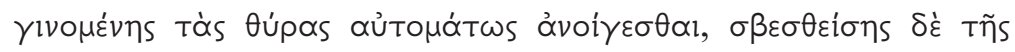

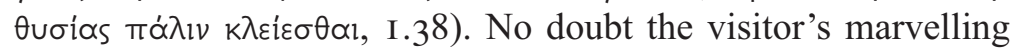
response was meant to be stimulated further still by additional sensory effects, such as the automatic sounding of "the din of trumpets on the opening of the temple doors' ( $\theta u p \tilde{\omega} v$

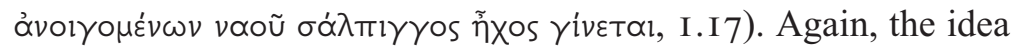
was surely to create an impression of a divine epiphany as a succession of escalating visual and aural thaumata potentially greeted the visitor to a temple decked out with automata and automatous devices.

But marvellous automata relating to the religious sphere are not the only type of automatic device which Hero describes in these two treatises. The second half of the Peri Automatopoietikes moves on to another location which this study has shown to be a potent source of thauma: the theatre. Hero begins by telling us that his earlier Hellenistic predecessor, Philo of Byzantium, was well known for small-scale static automata which displayed versions of theatrical performances in miniature theatres placed atop small pillars (20.I-5), before going on to describe one such display: a performance of the story of Nauplius, possibly based on Sophocles' Nauplius Pyrkaeus. ${ }^{\text {I3 }}$ Hero first outlines how these miniature theatrical automata operate by describing how the

I3 On the miniature theatre's probable depiction of Sophocles' Nauplius Pyrkaeus see Marshall (2003) 26I-79; cf. also Beacham (2013) I 5-39. On the plot and remaining fragments of this Sophoclean play see Sutton (I984) 82-4 and Lloyd-Jones (I996) 2 I $8-25$. 
small-scale performances begin when the theatre doors open and the action proceeds to play of its own accord (2I.I). A painted backdrop at the back of the theatre changes periodically as figures move on and off the stage and perform assorted movements to narrate the actions of the play (22.I). The first scene (22.3-4) depicts Greeks repairing their ships, and includes individual figures moving around and using saws, axes and hammers along with accompanying appropriate noises - a great din, Hero explicitly

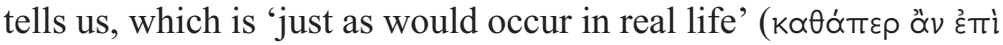

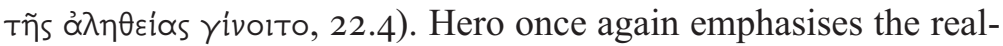
istic nature of the automatic performance when he notes that the next scene goes on to show the recently repaired Greek ships being launched and sailing across the field of vision with 'dolphins often swimming alongside, sometimes diving into the sea, and some-

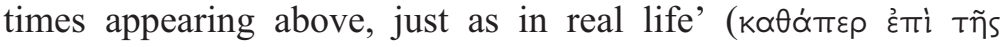
$\alpha \lambda \eta \theta \varepsilon i \alpha s, 22.5$ ), demonstrating that mimetic verisimilitude is clearly an important aspect of these miniature performances, despite their reduced scale. After the dolphins have appeared beside the ships, the sea turns stormy and Nauplius appears, holding a torch, with Athene beside him (22.5). The ships are then wrecked and Locrian Ajax is shown swimming; Athene appears above him on a crane and a lightning bolt (accompanied by the sound of thunder) falls upon the Greek hero, who disappears from view. The climax of the story thus reached, the theatre doors close, and the miniature theatrical performance is over (22.6).

As these examples from Hero's mechanical treatises suggest, the questions which developed over the course of the Classical period surrounding the relationship between thauma and the gods, thauma and the products of human craft, and the dividing line between natural and artificial thaumata continued to develop in tandem with developments in scientific and philosophical thinking in the later Hellenistic period. As a result, the development of actual automatous mechanisms is an ideal area to focus on as a means of thinking about the continuing importance of thauma in religious, philosophical and scientific discourse in the later Hellenistic and Roman worlds. 


\subsection{Mera Miracula: Thauma, Textuality and the Marvels of Aulus Gellius' Noctes Atticae}

The development of textual collections of thaumata, and the idea of the text itself as something capable of provoking thauma, has been one of the key shifts in the concept of what a marvel is and does traced out in this book. This final section returns to the significance of the entextualisation of Greek marvels through an examination of the earliest extant description of the reading and use of Greek paradoxographical collections which remains to us from antiquity. This intriguing account of an encounter with Greek marvels appears in Aulus Gellius' Noctes Atticae, a second-century CE miscellanistic work containing, among many other things, varied discussions concerning Greek and Roman culture, literature, language, grammar, history and philosophy. Throughout this miscellanistic work Gellius frequently scatters autobiographical accounts and anecdotes relating to his own life and education, and also occasionally to the exploits of his group of learned and aristocratic friends. It is in one such autobiographical passage that he recounts a seemingly formative encounter with Greek paradoxographical collections when he describes himself stumbling across a battered and slightly seedy job lot of Greek book rolls at the stall of a bookseller in the Italian port town of Brundisium (9.4. I-5):

cum e Graecia in Italiam rediremus et Brundisium iremus egressique e naui in terram in portu illo inclito spatiaremur, quem Q. Ennius remotiore paulum, sed admodum scito uocabulo 'praepetem' appellauit, fasces librorum uenalium expositos uidimus. atque ego auide statim pergo ad libros. erant autem isti omnes libri Graeci miraculorum fabularumque pleni, res inauditae, incredulae, scriptores ueteres non paruae auctoritatis: Aristeas Proconnesius et Isigonus Nicaeensis et Ctesias et Onesicritus et Philostephanus et Hegesias; ipsa autem uolumina ex diutino situ squalebant et habitu aspectuque taetro erant. accessi tamen percontatusque pretium sum et, adductus mira atque insperata uilitate libros plurimos aere pauco emo eosque omnis duabus proximis noctibus cursim transeo; atque in legendo carpsi exinde quaedam et notaui mirabilia et scriptoribus fere nostris intemptata eaque his commentariis aspersi, ut qui eos lectitarit ne rudis omnino et ơvíkoos inter istiusmodi rerum auditiones reperiatur.

When we were coming back to Italy from Greece and reached Brundisium, after disembarking from the ship onto land we were strolling about in that famous harbour, which Quintus Ennius - using an epithet which is somewhat obscure, 


\section{Epilogue: Thaumata Polla}

but extremely erudite - called 'auspicious'. ${ }^{14}$ We saw bundles of books placed out for sale. Straightaway I eagerly went over to the books. Now, all of these books were in Greek, full of marvellous stories, unheard of things, unbelievable things, by ancient writers of no little authority: Aristeas of Proconnesus and Isigonus of Nicaea and Ctesias and Onesicritus and Philostephanus and Hegesias. But the rolls themselves were filthy from long decay, repulsive in condition and appearance. Even so I approached and asked their price, and attracted by their marvellous and unexpected cheapness I bought very many books for very little money, and I went through them all swiftly over the course of two nights. And in the course of reading I picked out certain things from them and noted them down, marvellous things almost completely unexplored by Latin writers, and I scattered these things in these writings of mine, so that anyone who reads them will not be found to be completely uncultivated and ảvíkoos [= not having heard something, ignorant] when hearing matters of this type.

One of the most striking aspects of the way in which the encounter with books containing marvels is framed here is the manner in which wonders are presented as distinctly Greek. For some reason, Gellius takes the time in the middle of his own miscellanistic collection to provide a supposedly autobiographical sketch which emphasises that the practice of composing books entirely full of wonder-provoking stories is something that Greek writers might do, but certainly not Roman ones. All of the texts Gellius purports to stumble across are in Greek, and they do not contain the occasional smattering of mirabilia - these books are absolutely stuffed full of marvels (omnes libri Graeci miraculorum fabularumque pleni). Furthermore, this kind of material is supposedly almost impossible to find in native Latin writers: unlike Greek writers, those fashioning Latin texts have scarcely attempted to compose this kind of material (scriptoribus fere nostris intemptata) - at least according to Gellius.

This emphasis on the Greekness of this marvellous material is clearly an attempted distancing effect on Gellius' part. The fact that the books are by ancient writers (scriptores ueteres), and that the rolls are themselves clearly so old that they have become filthy and decayed through long neglect (uolumina ex diutino situ

${ }^{14}$ Gellius had already cited the full Ennian line in which this word is found ('Brundisium encircled with a beautiful, auspicious (praepete) harbour' = Enn. Ann. 457) earlier on in his work during a lengthy discussion at NA 7.6 of use of the adjective praepes, which is usually applied to birds and literally means 'straight-flying' or 'swift-flying', but comes to mean 'well-favoured, auspicious' through its association with augury. 


\subsection{Mera Miracula}

squalebant et habitu aspectuque taetro erant), serves a similar purpose. The suggestion seems to be that by the second century $\mathrm{CE}$, marvels now truly belong to the Greek past. The undertone in this passage is clear: marvellous material is dangerous, alluring and potentially destructive. There is even perhaps a sense that the overindulgence in mirabilia, this concentration on wonder, has led to the decay of Greek culture itself. Are the squalid uolumina metonymic stand-ins here for Greek cultural power? Is an unhealthy interest in marvels to blame for the Greeks' cultural decay, at least from a Roman point of view?

At the same time, there is a strong sense in this passage that the marvellous Greek material is inherently ambivalent and doubleedged: tawdry and cheap, as reflected in the physical condition and price of the books (mira atque insperata uilitate libros plurimos aere pauco emo), yet simultaneously authoritative and attractive, worthy of Gellius' enthusiasm as he rushes avidly forth to buy the rolls in bulk. After all, these writers are of no small authority (non paruae auctoritatis), as he himself admits. Indeed, each named author was well-known in antiquity for either ethnographic accounts of far-off places, travel narratives or historical writing which contained, at least in part, descriptions of natural and manmade wonders. The first writer mentioned by Gellius, Aristeas of Proconnesus, is a particularly ancient and authoritative figure: a semi-mythical epic poet, supposedly dating to the seventh century BCE, he was famous in antiquity both for his supposed shamanic ability to leave his body and travel to distant lands, and for the composition of an epic poem called the Arimaspea. This poem told of Aristeas' journey to the land of the Scythians and Issedones in the far north and described the things which he learned on his travels about the one-eyed Arimaspeans and Hyperboreans who inhabited the very furthest northern edges of the earth. ${ }^{I 5}$ The most detailed and famous account of Aristeas' abilities and poem is found in another later account of a distant land, the Scythian logos in book four of Herodotus' Histories (4.I3-I6). But it was not the content of the Arimaspea alone

${ }^{15}$ See Bolton (I962) II9-4I for a discussion of Aristeas' life, and pp. 74-II8 for a discussion of the potential form and content of the Arimaspea. 


\section{Epilogue: Thaumata Polla}

which was considered to be marvellous in later periods. Aristeas himself also later appears as a marvel at the beginning of Apollonius Paradoxographus' marvel-collection. ${ }^{\text {I6 }}$ The work of the other authors mentioned is also commonly cited in later paradoxographical collections. Isigonus of Nicaea, a paradoxographer of the first century BCE or first century CE, wrote a work entitled Unbelievable Things ('A seems to have contained marvels relating to the natural world (particularly wondrous bodies of water): this text was itself drawn upon and excerpted by later paradoxographers in their own marvel collections. ${ }^{\text {I7 }}$ The doctor and historian Ctesias (late fifth century-early fourth century BCE) is the writer mentioned by Gellius who is best known to us in the modern world: his historical and ethnographic accounts of eastern lands, Persica and Indica, provided material for later paradoxographers as well. ${ }^{\text {I8 }}$ Callimachus' pupil Philostephanus of Cyrene (third century $\mathrm{BCE}$ ), as mentioned in Chapter 3, is known to have produced verse epigrams on paradoxographical themes which were cited in later marvel-collections. ${ }^{\text {I9 }}$ The two other authors mentioned by Gellius are both known for writing histories about Alexander the Great which probably contained ethnographic marvels relating to the lands he visited on campaign: Hegesias of Magnesia (third century BCE) and Onesicritus of Astypalaea (c. 380-300 BCE), a man who we know actually accompanied Alexander on his eastern travels.

As well as provoking paradoxical feelings of attraction and repulsion, these book rolls stuffed with marvels also seem to call forth a peculiarly paradoxographical response in the author of the Noctes himself, as he plunges into these thaumatic Greek texts of the past and avidly seizes any appealing or relevant mirabilia

${ }^{16}$ See entry 2 in Apollonius Paradoxographus' Marvellous Investigations (= PGR I 20-3).

${ }^{17}$ See $P G R$ I $46-8$ for fragments and testimonia relating to Isigonus.

18 For example, the Hellenistic paradoxographical collection of Antigonus of Carystus (see PGR 3I-IO9 for the text of this marvel-collection) contains many marvels which ultimately derive from Ctesias' work: see e.g. entries I 5 b, I 45, I 50, I65-6; cf. entries I 7 and 20 in Apollonius Paradoxographus' marvel-collection (see PGR I28-3I). On the relation of Ctesias' work to Hellenistic paradoxography, see Nichols (20I8) 3-I6.

19 See $P G R 2 \mathrm{I}-3$ for testimonia and fragments relating to Philostephanus' paradoxographical output. On Hellenistic verse paradoxography see Chapter 3, Section I. 
needed to adorn his own work. Gellius is careful to present himself as the ultimate connoisseur of marvels, a perfect paradoxographer exercising necessary Roman discernment to neuter the potentially dangerous and distracting power of the Greek thaumata he has stumbled across. He knows precisely how to properly prune and cull this material (in legendo carpsi exinde); he knows which marvels need to be noted down (notaui mirabilia); he knows how and where and when to scatter and arrange marvels in his own writings (eaque his commentariis aspersi). In fact, the description of his method here recalls the earlier discussion of his wider methodology in the preface of the Noctes. There Gellius tells us that unlike many previous writers of miscellanistic collections, 'especially Greek ones' (maxime Graeci), who after eagerly reading many varied accounts ... indiscriminately swept things together, aiming at sheer quantity alone' (sine cura discriminis solam copiam sectati conuerrebant, NA pr. II), he himself excerpts and reports only a few choice things (modica ex his eaque sola accepi) which might either lead others towards a further 'desire for learning' (eruditionis cupidinem) or 'save men from an undoubtedly shameful and uncultivated ignorance of important matters and words' (homines ... a turpi certe agrestique rerum atque uerborum imperitia uindicarent, NA pr. I2). This idea that Gellius' arts of excerption are able to rescue his readers from the spectre of shameful ignorance is repeated once again in the anecdote about his encounter with marvellous Greek texts at Brundisium when the reader is assured that the author's judicious sprinkling of choice Greek marvels in the Latin Noctes will ensure that none of his readers will ever run the risk of being considered 'completely uncultivated and ởv่koos (ignorant)'.

At the opening of this anecdote Gellius thus presents himself as the ideal mediating lens through which marvellous Greek thaumata, shorn of any particularly unappealing, unbelievable or uneducative aspects through a careful process of selection, filtration and refinement, might be enjoyed by the curious and cultivated Roman reader. In fact, the very setting of the anecdote hints at the significance of issues of cultural mediation which the appearance of marvellous Greek texts will go on to raise, since Brundisium, as the main Italian port through which Greece was 
accessed in antiquity, is a natural setting for an encounter which mediates between the two cultures of Greece and Rome. Even the throwaway reference to Quintus Ennius - an undoubtedly learned but seemingly redundant detail at first glance - is relevant to the ideas of cultural mediation and translation which Gellius raises through his encounter with Greek thaumata in this passage, since just as Ennius famously brought hexameter epic from Greece to Rome, Gellius too will transfigure a Greek mode of writing into its appropriate Roman form. In this sense, then, Brundisium really is an 'auspicious' place, as the Ennian epithet which Gellius uses to describe the port suggests, since this seemingly chance encounter with Greek marvels has the potential to both elevate the author of the Noctes Atticae to the head of the Latin miscellanistic tradition and position him as a new sort of Ennian heir: 'As Ennius translated Greek hexameters into Latin epic, I will transform distracting Greek thaumata into useful and refined Latin mirabilia', Gellius almost seems to say to us in this passage. ${ }^{20}$

But is Gellius' claim to innovation true? Had native Latin writers really resisted the lure of the Greek marvellous before Gellius came along to put them straight? The answers to these questions become clearer as we continue through the passage and discover which specific Greek thaumata have been selected and recorded for the edification of Roman readers over the course of Gellius' two nights of reading. Gellius begins (9.4.6) with material about strange and wonderful distant peoples, such as the Scythian cannibals called Anthropophagoi, the Arimaspians with one eye in the middle of their foreheads and another unnamed far-northern people whose feet are turned backwards. After mentioning two other strange peoples - men from Albania whose hair turns white in childhood and who can see better in the night than the day, and the Sauromatae, who are accustomed to eating only once every two days - Gellius suddenly casually mentions another writer's

${ }^{20}$ Brundisium is of course already an extremely resonant location in Latin literature, which helps to explain why Gellius refers to it as portu illo inclito at the opening of 9.4 (see Lindermann (2006) I22). The most famous extant examples of the port's importance in the Latin literary tradition are probably its place as the supposed location of Pacuvius' birth and Virgil's death (see Gowers (2OI2) 2I 2-I3), and as the end point of Horace's journey with Maecenas in the final line of Sat. I.5 (Brundisium longae finis chartaeque uiaeque est, I04). 
name in a way that might make us suddenly stop and wonder (9.4.7):

id etiam in isdem libris scriptum offendimus, quod postea in libro quoque Plinii Secundi naturalis historiae septimo legi, esse quasdam in terra Africa hominum familias uoce atque lingua effascinantium.

Furthermore, in those same books I came upon this account, which afterwards I also read in the seventh book of Pliny's Natural History, that in the land of Africa there are certain bands of men who perform enchantments with their voices and tongues.

Seeing as Gellius has already taken such pains to insist that the type of marvellous material contained within the Greek book rolls he stumbled across at Brundisium has been 'almost completely unexplored by Latin writers' (scriptoribus fere nostris intemptata, 9.4.5), it seems strange that he should here mention that Pliny the Elder, a fellow Latin writer, had also already shown a similar interest in precisely the same Greek thaumata. But what is even stranger is the fact that every marvel Gellius has so far mentioned in this passage, including those listed above, is also found in the seventh book of Pliny's Natural History, reported in precisely the same order. ${ }^{2 I}$ In fact, the most likely scenario seems to be that Gellius has not stumbled across any Greek books in Brundisium at all, but has excerpted all of this material from a single book of Pliny. ${ }^{22}$ In Gellius' world, despite his protestations, marvels are firmly Roman already. ${ }^{23}$

${ }^{21}$ See Plin. HN 7.9-26. On Gellius' dependence on Pliny at $N A$ 9.4, see Holford-Strevens (I988) 30-I, 50-I, Gunderson (2009) I85, Keulen (2009) 200-I and Howley (2018) I I 4-20, I23-34. On Gellius' contested relationship with Pliny in general, see HolfordStrevens (I988) I 2 I-2, Keulen (2004) 238-4I, Gunderson (2009) I 8 I-5 and Howley (20I8) I I 2-56. On Pliny's pronounced interest in mirabilia and wonder in the $H N$ see Beagon (I992) 8-I I, (2005) I 7-24, (2007) I9-40 and (20I I) 80-6, Conte (I994) 85-6, Carey (2003) 84-IOI, Murphy (2004) I 8-22, Naas (2004) 253-64 and (20I I) 57-70, Woolf (20II) 8I-5.

${ }^{22}$ See Zetzel (I98I) 59 and Holford-Strevens (I982) 65-8 on the seemingly fictional nature of the anecdote at $N A$ 9.4.

23 In fact, Roman interest in collecting marvellous material goes back at least to Varro and Cicero: the former is said (at Macrob. Sat. 3.I 5.8) to have written a book entitled Gallus de admirandis; the latter supposedly wrote a book of marvels entitled Admiranda, which is cited twice in Plin. HN 3I.I2 (Cicero in admirandis posuit) and 3I.5I (quod admirandis suis inseruit $M$. Cicero). Pliny also made great use of the work on marvels by his contemporary Mucianus in the HN: see Ash (2007) I-I7 on the contents and purpose of his work. 
In the end, Gellius' attempt to distance Roman culture from marvellous modes of Greek writing does not stand up to much scrutiny at all. But the way in which he characterises the wonders and the feeling of wonder as distinctively Greek in this account certainly suggests that the writing of marvels is something of a contested practice by this period. This is surely partly because, by the time Gellius is writing the Noctes, the already-rich textual tradition of wonder has made marvel-writing into an extremely contested mode which almost by definition raises questions of fictionality and belief. After all, is it really ever possible to trust the authority of previous writers fully when it comes to 'unheard of things, unbelievable things' (res inauditae, incredulae, 9.4)? Perhaps it is no wonder then that by second century CE it is not only the content of the material Gellius describes which is beyond belief but even his marvellous description of an autoptic encounter with the marvel-writing of the past.

One of the most obvious reasons why Gellius' attitude towards mirabilia is so ambivalent in the Noctes is the fact that, at certain moments, his own work seems to come perilously close to assuming the paradoxographical form of marvel-writing. This risk is clearest a few books later in the Noctes, when entextualised marvels make a further appearance in another Gellian autobiographical anecdote. This narrative relates to the composition of the Noctes itself (I4.6.I-3):

homo nobis familiaris, in litterarum cultu non ignobilis magnamque aetatis partem in libris uersatus, 'adiutum' inquit 'ornatumque uolo ire Noctes tuas' et simul dat mihi librum grandi uolumine doctrinae omnigenus, ut ipse dicebat, praescatentem, quem sibi elaboratum esse ait ex multis et uariis et remotis lectionibus, ut ex eo sumerem, quantum liberet rerum memoria dignarum. accipio cupidus et libens, tamquam si copiae cornum nactus essem, et recondo me penitus, ut sine arbitris legam. atque ibi scripta erant, pro Iuppiter, mera miracula: quo nomine fuerit, qui primus 'grammaticus' appellatus est; et quot fuerint Pythagorae nobiles, quot Hippocratae; et cuiusmodi fuisse Homerus dicat in Vlixis domo $\lambda \propto u ́ p \eta v$; et quam ob causam Telemachus cubans iunctim sibi cubantem Pisistratum non manu adtigerit, sed pedis ictu excitarit; et Euryclia Telemachum quo genere claustri incluserit; et quapropter idem poeta rosam non norit, oleum ex rosa norit.

A friend of mine, not unknown on the literary scene and well-versed with it for the majority of his life, said to me: 'I'd like to help you polish up your Nights', 


\subsection{Mera Miracula}

straightaway presenting me with a book roll of massive bulk, bubbling over, as he himself put it, with knowledge of every sort. He said that he had put it together from wide and varied and recondite reading, and that I should borrow from it as much as I thought worthy of recording. I received the book greedily and gladly, as though I'd obtained the horn of plenty, and hid myself away so that I could read it without witnesses. But - by Jupiter! - the things that were written in it were pure marvels! The name of the first man who was called a 'grammarian'; how many famous men were named Pythagoras, and how many were named Hippocrates; what sort of thing

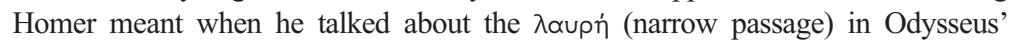
house, ${ }^{24}$ the reason why Telemachus, while lying down, woke up Pisistratus, who was lying next to him, by striking him with his foot rather than touching him with his hand, ${ }^{25}$ with what kind of bolt Eurycleia shut Telemachus in; ${ }^{26}$ and for what reason the same poet has no knowledge of roses, but does know about rose oil. ${ }^{27}$

Gellius' list of 'pure marvels' (mera miracula) does not end here. He continues in a similar vein (I4.6.3-4): the massive book roll also contained the names of the companions of Odysseus whom Scylla snatched away and tore apart, as well as meditations on a muchdebated topic of Homeric geography, the question of whether Odysseus sailed around the 'inner' (i.e. the Mediterranean) or 'outer' sea (i.e. the Atlantic) during his wanderings. The book roll even includes examples of Homeric verses which are isopsephic (i.e. consecutive lines which, when each letter in the line is assigned a numeric value, add up to the same total), Homeric acrostics spelling out the names of characters, and lines in which each word is a syllable longer than the preceding word. ${ }^{28}$ Other sorts of intractable peculiarities relating to the Homeric texts are not excluded: for example, Menelaus' description in the Odyssey of his encounter with astonishingly fertile Libyan ewes during his wanderings after the Trojan War is transformed into a zoological question about the ability of livestock to breed three times within a year, while the precise ordering of the multiple layers of Achilles' famous shield in the Iliad becomes yet another problem to be discussed. ${ }^{29}$

24 Od. 22.I $28,22 . \mathrm{I} 37$.

5 Od. I 5.44-5.

Od. I.44I-2.

27 Il. $23 . \mathrm{I} 86$.

28 On such phenomena in the Homeric poems and ancient responses to them see Hilton (20I I) and (20I3).

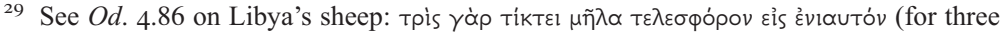
times the sheep give birth in the course of a full year). This claim of hyper-fertility really 
There are two things which immediately strike us about the miracula that Gellius lists here. Almost all of these 'marvels' are typical questions of ancient literary scholarship, and all relate to Greek figures or texts; most, in fact, relate to the Homeric poems. In the Homeric scholia, and in other extant testimonia of ancient debates in Homeric scholarship, we find evidence that many of the issues which Gellius here mentions were actually discussed in ancient scholarship on the Homeric text. For example, the seemingly irrelevant question of why Telemachus prods Pisistratus awake with his foot rather than his hand really does seem to have exercised Alexandrian critics. In the remaining scholia on Odyssey I5.45 it is suggested that certain critics may have considered the line to be spurious because it does not seem fitting for Telemachus to use such a forceful action, even if the expression

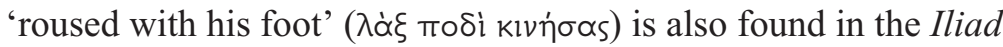
(IO.I58) when Nestor kicks the sleeping Diomedes awake - an action which the scholiast argues is fitting because old age renders Nestor unable to bend down and touch Diomedes with his hand; for Telemachus, however, there is no such excuse. ${ }^{30}$ The other questions mentioned by Gellius also attracted comment among Homeric scholars and commentators to a greater or lesser degree. This ranged from clarification of the meaning of specific unusual words and comment on stylistic aspects of the text, to infamous full-blown critical debates between famous Homeric scholars, such as Aristarchus and Crates' argument about the geographical

did cause ancient critics to raise their eyebrows: see e.g. $\Sigma$ ad. $O d .4 .86$. The wondrous hyper-fertility of Libya is something other writers comment upon in antiquity: see e.g. Hdt 4.I99 on the three harvest seasons of Cyrene, a phenomenon which he declares

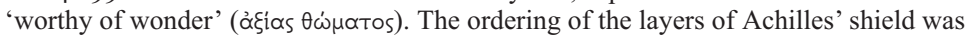
another cause of comment and dispute in ancient Homeric scholarship: the problem centred on Il. 20.267-72, which tells us that Aeneas' spear passed through two layers of bronze before stopping in the third layer, made of gold, and leaving two layers of tin untouched. The question is how or why the spear would be stopped by the (outer?) layer of gold while managing to penetrate the harder or more internal bronze layers. Aristotle raises this as a Homeric question at Poet. I46Ia3I-5 but provides no answer. Later Hellenistic Homeric scholars were equally troubled by such a seeming incongruity: Aristarchus perhaps athetised the lines as a result (see $\Sigma$ ad. Il. 20.269-72). For the responses of modern critics to this problem see Edwards (I99I) 323.

${ }^{30}$ See $\Sigma$ ad. $O d$. I5.45; the issue is also mentioned at $\Sigma$ ad. Il. IO.I58. The scholiast's reasoning concerning Nestor's old age is obviously nonsensical given his continued vigour in Iliadic battle. See also further discussion of the Odyssean passage at Hoekstra (I989) 233-4. 
location, and by extension the historical accuracy, of Odysseus' wanderings. ${ }^{3 \text { I }}$

How does Gellius respond to this book overflowing with Greek literary scholarship? Given that by this point in the Noctes his persona as an eager yet discriminating literary scholar is already well-developed, we might expect him to approve of his friend's learned book. But the previous designation of the book's contents as 'pure marvels' (mera miracula) turns out to have been a hint at Gellius' forthcoming negative reaction (I 4.6.5):

haec atque item alia multa istiusmodi scripta in eo libro fuerunt. quem cum statim

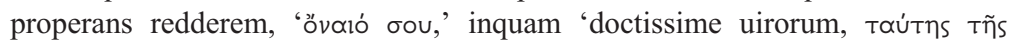

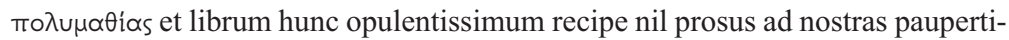
nas litteras congruentem'.

These things and many other things of the same kind were written in that book. And rushing to return it to him immediately I said: 'May you profit from this display of wide knowledge, most learned man! But take back this most extravagant book: it has nothing at all in common with my poor writings'.

Gellius' response makes clear that his description of the book's contents as 'pure marvels' was far from a positive one. But this reaction also carries a hint of irony. After all, the Noctes is full of discussions similar to the ones which Gellius disdains in this instance. There is, however, one important difference between the discussions in the marvel-filled book belonging to the learned literary friend and the Noctes itself: Gellius' literary discussions almost invariably relate to Latin rather than Greek texts. ${ }^{32}$

${ }^{31}$ For discussions of the specific Homeric words and problems mentioned by Gellius see e.g. $\Sigma$ ad. $O d$. 22.I28, which defines the word $\lambda \alpha u p \eta$ as a 'narrow passage'; $\Sigma$ ad. Od. I.44 I-2 for traces of a long discussion of the meaning of each word which relates to fastening the door shut at $O d$. I.44I-2; $\Sigma$ ad. Il. 23 . I 86 on Homer's mention of rose oil. Traces of this famous debate between Aristarchus and Crates concerning the location of Odysseus' wanderings survive in later ancient texts: book one of Strabo's Geography is particularly important in this regard. On later discussions and debates concerning Odysseus' wanderings see e.g. Porter (I992) 67-II4, Romm (I992) I86-90, Buonajuto (I996) I-8 and Lightfoot (20I9b) 67I-97.

32 See e.g. Gellius' discussions of textual issues/issues of interpretation/anecdotes about Virgil: $N A$ I.2 I , 2.6, 2. I6, 5.8, 6.20, 7.6, 8.5, 9.9, 9. I0, I0.I 6, I3.27, I6.6, I 7.Io. Gellius very rarely weighs in on issues relating to Homer or the Homeric text. He does so most explicitly at 3.II, where he criticises Accius for arguing that Hesiod was older than Homer. The emphasis here, however, is on proving Accius wrong, rather than genuinely inquiring about the relative dates of Homer and Hesiod. 
We see once again that for Gellius, wonder and the marvellous have become terms which represent complex responses to the type of textual material in which his own literary output is grounded. On the one hand, he is clearly trying to distance his own miscellanistic text from the style and content of other contemporary works, though it is also clear that his own writing is in many ways very similar. Even typical questions of textual scholarship can now be labelled as 'marvels' of a sort in the Noctes; it is striking that in this chapter we see the same combination of eager desire and enthusiasm at the opportunity to experience a new text as Gellius takes the book from his friend 'greedily and gladly' (cupidus et libens), and then eventual disgust and rejection felt towards these textual marvels, just as the marvel-filled Greek texts which he supposedly found in Brundisium are first consumed 'greedily' (auide, 9.4.2), before a seemingly inevitable sense of 'disgust' (taedium, 9.4. I2) grips Gellius once he has noted down the thaumata contained within the Greek book rolls. ${ }^{33}$ By the time Gellius writes the Noctes, wonder has become a way of thinking about how texts relate to other texts, and about the idea of the text itself as a kind of marvel.

This study has suggested that it is in the Hellenistic paradoxographical collection that wonder can first explicitly be seen as an important prism through which to view the means by which relationships between literary texts, and the effects of these relationships, are constructed. As Gellius' Noctes Atticae suggests, these relationships become only more complicated once they are transfigured and transformed within the traditions of Latin literature and scholarship. It is no accident that Gellius in his own work configures the marvellous as an intensely Greek textual experience, even when other Roman writers like Pliny are the sources of the information he is specifically labelling as wondrous and purely Hellenic. The Greekness of the concept of wonder in Latin texts is an issue that remains to be explored. This book has shown that some of the most familiar texts from the Archaic to early

33 See also NA I0.I2.I-6, where a similar sense of 'disgust' (pertaesum est) overcomes Gellius when he records some mirabilia which Pliny the Elder attributed to the Greek philosopher Democritus. On Gellius' attitude towards Pliny and mirabilia at NA IO.I2 see e.g. Gunderson (2009) I 83-4 and Howley (2018) I35-42. 


\subsection{Mera Miracula}

Hellenistic period provide new perspectives on Greek culture itself when viewed through the lens of wonder. The new perspectives on Greek and Roman culture that can be reached by assessing the impact of the Greek marvellous on Rome - and vice versa remain to be examined. 